\title{
Reflections on the Construction of Teachers' Ethics in Ideological and Political Education in Colleges and Universities
}

\author{
Yuxia Ding \\ School of Ideological and Political Education \\ Wuhan Donghu University \\ Wuhan, China
}

\begin{abstract}
The teachers of ideological and political education in colleges and universities are the most important groups of ideological and political education for college students. The teachers' moral status is related to the cultivation of the qualified builders and reliable successors of socialism with Chinese characteristics. The General Secretary Xi Jinping's important speech at the National Conference on Ideological and Political Work in Colleges and Universities made clear demands on strengthening and improving the ideological and political work in colleges and universities in the new situation. And it also gave the responsibility and historic mission to the teachers of the ideological and political education in the university in new era. The teachers of ideological and political education should be good teachers with ideal and faith, moral sentiment, solid knowledge, and kindness.
\end{abstract}

Keywords-ideological and political course in colleges and universities; good teachers; teachers' ethics

\section{INTRODUCTION}

The ideological and political theory courses in colleges and universities are the historical traditions and unique advantages of the Communist Party of China in carrying out ideological and political work in colleges and universities. It is an important feature of socialist higher education. It undertakes the important task of carrying out systematic Marxist theoretical education for college students. It is the main way of political work. And it plays a crucial role in the fundamental issue of "what kind of person to cultivate, how to cultivate and cultivate for what." We should make good use of this main channel, enhance the affinity and pertinence of ideological and political education, and meet the needs and expectations of students' growth and development. The teachers of ideological and political theory play an important role. "The Opinions on Strengthening and Improving Ideological and Political Work in Colleges and Universities in the New Situation" puts forward that we should make efforts to cultivate a good teacher who has ideals and beliefs, moral integrity, solid knowledge and loving heart. Thus, teachers of ideological and political theory who have noble virtue, firm faith, profound learning and theoretical foundation are the keys to make a good course of ideological and political theory.

\section{TEACHERS WITH NOBLE VIRTUE AND BENEVOLENCE WOULD LOVE STUDENTS AND MAKE TEACHING WITH VIRTUE}

Teachers should set oneself an example to the students, and act as a mirror. They win the respect and admiration of students with their noble charisma. To love students is a prerequisite for ideological and political work. Xi Jinping pointed out that education was the cause with "benevolence and love". Love is the soul of education, and there is no education without love. Since ancient times, outstanding teachers love students as children. As a teacher, Confucius is the model. Chen Kang, a student of Confucius thought that Confucius must teach his son more knowledge than his students. He asked Kong Li, Confucius's son that what his father taught him? Kong Li said, his father taught him that "the people would have no words without learning poetry; the people would stand up without learning ceremony." However, Confucius had taught this knowledge to his students' long time ago. Chen Kang exclaimed: "I have one question, and understand three things. Poetry can be taught to have words, and learning ceremony can stand up. The wise people would be fair to all the people." 1To love the students should be put in the first place. With this attitude, teachers and students can be in a state of harmony, and many things would be solved. To love students is to be studentoriented. The teachers should respect and trust the students, and take care of students. If they are our students, the teachers should treat them equally. The teachers should work with emotion. And then, the ideological and political education would have temperature and enthusiasm. The students can feel that the teachers are really concerned about them, and it would shorten the distance between teachers and students. This kind of love has the correct guidance on the thoughts of the students. And it is concerned about the lives of students.

"The Analects of Confucius· Jishi", Wang Guoxuan, Zhang Yanying and others Annotation, "Four Books", Beijing: Zhonghua Book Company, 2007 edition, p84. 
For example, teachers who teach the course of ideological and moral cultivation and law basis are facing with the newly recruited students. They enter the university from a normative and orderly senior high school, need to take the initiative in all aspects, and would inevitably have troubles in all aspects of life and study. In the early period of admission, some students feel an indescribable emptiness and confusion without stress and internal force. There are many excellent students in new environment. The students aren't willing to be mediocrity. However, they are difficult to break the situation. Many students would easily fall from the clouds of confidence to the bottom of inferiority. Selfcentered inertia often leads to interpersonal tension. The students would feel lonely and depressed. And the pressure of employment is growth. All of this, they are eager to talk to one of their trusted teachers or elders for psychological comfort and behavioral guidance. Therefore, teachers of ideological and political theory should pay attention to the practical problems what students are facing with, take the initiative to approach the students, chat with the students, understand their life, their hobbies, their social awareness, their thoughts, their needs and what students are doing. The teachers should grasp the new changes and characteristics of students, respect each student's growth and development needs, and follow the law of teaching and education and the law of student growth. The teachers should find points of convergence with the ideological and political theory from the actual situation, and guide students to learn the society, know oneself, adjust oneself, and adapt to the society. In the process of solving problems for students, the teachers should meet the needs of students' growth. And then, the students can participate in and support the teaching of ideological and political theory. Of course, the teachers of ideological and political theory aren't saints. And they can't solve everything. Also, they have their own limitations of knowledge, thinking and ability. However, the teachers would have firm love for the students. It is believed that any kinds of difficulties can be solved. And the teachers should take care of students. However, it should have principle. The teachers shouldn't indulge any students. And the teachers should guide students to do anything with discipline. The construction of a harmonious society can't be inseparable from the discipline and order. Otherwise, there would have confusion and disorder in the society. Students accept you, and they would take the initiative to accept your education.

\section{THE TEACHERS WITH SOLID KNOWLEDGE AND REAL FAITH SHOUld CONVINCE PEOPLE BY REASONING}

The teaching should be reasonable to serve people, which are the core competencies of the ideological and political theory. Marxism holds that as long as theory persuades people, it can grasp the masses; and if the theory is thorough, it can persuade people. The so-called thoroughness is to grasp the essence of things. General Secretary, Xi Jinping emphasizes that the evangelist must firstly understand and believe the morality. The teachers of colleges should insist that educators should be educated firstly, strive to become the propagator of advanced ideology and culture, and the staunch supporter of the party. And then, they can better shoulder the responsibility of the instructor and make guidance on the healthy growth of students. To do this, the teachers of ideological and political theory must enhance theoretical self-confidence and self-consciousness. At present, the main body of students in the course of ideological and political theory is the "post-95" college students. They have active thinking, broad vision, sharp view and good thinking. They are also confused, and they also expect to learn Marxist theory. In the process of teaching, the teachers often quoted the code. And they had talked about a lot of the content. It is close with the actual deduction. It lacks insightful theoretical sense of ascension. And it is difficult to play the power of truth. In order to enhance theoretical persuasion and promote the penetrating power of the classroom, we must conscientiously study Marxist theory, and continuously raise the theoretical level of socialism with Chinese characteristics. And we should work hard to know the truth. The course of ideological and political theory includes a lot of content of politics, economics, culture and sociology and other disciplines. And it requires the teachers to have a wide range of knowledge, but also to understand the community. From the macro level, we should grasp the situation of the party and the state affairs, and promptly grasp the latest spirit of the central document. And we should be good at accepting and absorbing the latest information from the highest levels of decision-making. Therefore, as a teacher of ideological and political theory, we should conscientiously study General Secretary Xi Jinping's important speech and the new concept and new strategy of governing state affairs and politics, and enhance our political awareness, overall situation and core awareness. We should make a thorough understanding and grasp three fundamental theoretical issues, namely, we should know the fundamental issue of "to cultivate what kind of person and how to cultivate people and to cultivate people for whom?" We should serve the people, serve the state affairs of the CPC, and consolidates and develops the socialist system with Chinese characteristics, and make service for reform and opening up and socialist modernization. We should conscientiously strengthen the course of ideological and political theory with the spirit of General Secretary Xi Jinping's important speech. Teachers should pay attention to the careful collection of materials on the contents of the course, use information and data to properly interpret the theory, and pay attention to educating and guiding students to correctly understand the world and the development trend of China, correctly understand Chinese characteristics and international comparisons, and correctly understand the responsibilities and history of the times, correctly understand ambition, learn to use theory to analyze and solve practical problems, and effectively enhance students' access to the classes of ideological and political theory.

It should enhance the persuasiveness of the theory. And it is also necessary to excavate the theoretical depth with the times. It requires that the teachers of ideological and political theory should conduct in-depth studies on some major theoretical issues in teaching and transform themselves into their own research results. And then, the problems can be thoroughly explained. Then, it would be easy to understand. If we are just satisfied with the theoretical viewpoints on the textbooks, we will not conduct deep research on some major 
issues. And we can't answer some deep-seated problems in our teaching, which will inevitably reduce the attractiveness and contagion of the courses of ideological and political theory. Therefore, according to their own professional background, teachers can choose their own teaching and research directions and study the problems. And the teachers are willing to try without fearlessness and non-retreat. Then, the teachers would make achievements and enhance selfconfidence according to their practical background and school characteristics. In the classroom, the teachers could conquer the students with the theory and the power of truth.

\section{TO CUltivate THE STUdents With CAREFULNESS AND PATIENCE, AND TAKE THE STUDENTS AS THE OBJECTIVES}

Ussinsky, a Russian educator said: "If an educator wants to train people in all fields, he firstly must understand the students in all aspects." The meaning of "carefulness" is that the teachers understand and master every detail of every student. Due to various reasons, students' hobbies, virtues, deeds and habits are different during the process of their growth. They even have changes with age and educational environment, and some students are in line with the law of growth. However, the growth of some students is disorderly. And in the growth of some students, they have sudden events. And it has constituted a colorful, boundless big world. Therefore, teachers should actively and conscientiously understand or master moral character, conduct, or hobbies, habits and family education environment of every student. At the same time, they should often discover, observe and pay more attention to the development of students during a certain period of time. "Attentiveness" is a rigorous attitude of the teachers. Teachers should be conscientious and meticulous in all aspects of their work. Teachers should have universality, particularity and pertinence in their education. The students would fire their enthusiasms.

It is a long-term task to educate students. It requires patience. The teachers should observe carefully in everyday work, discover students' mistakes and honestly communicate with him. The students are able to accept it. For example, there is a student who likes to talk in class. And the teachers should talk to him for the first time. He said very frankly that the course of ideological and political theory had no effect on the fundamental transformation of his ideology and morals. At this time, in order to solve this problem, we must firstly change his thinking and understanding. However, we can't change this deeply. So, the teachers should talk with him for many times. As long as he makes mistakes, the teachers should talk to him for more times. And then, he would be touched, and he would also try to change bad habits. Later, he can do a good job with the teacher and actively cooperate. Human feelings are mutual, and the students can feel teacher's sincerity. The students should adhere to equal treatment with students, and encourage them to talk about their own ideas and real feelings. According to the specific circumstances, the teachers should do a specific analysis and correct guidance. Then, it would form a habit of exchange between teachers and students. In teaching, the teachers should set aside some time for the students each class. And then, the students would write down the curriculum or the community. According to the collation, the problems raised by students and existing problems are throughout the teaching process. The teachers should make targeted teaching. And the students would feel basic class. It does not flow in the form, and enables them to make improvement through the study.

\section{CONCLUSION}

In short, teachers of ideological and political theory should cultivate their own fields of responsibility, and implement the spirit of General Secretary Xi Jinping's speech in each specific work, earnestly, conscientiously and conscientiously do everything in manner. And the teachers should strengthen the course of the ideological and political theory in the improvement. And the teachers should be good and talkative. They should speak new ideas and characteristics. Then, the students would really like and benefit for life.

\section{REFERENCES}

[1] Xi Jinping emphasized at the National Conference on Ideological and Political Work in Colleges and Universities that the ideological and political work should be conducted through the entire process of education and teaching to create a new situation in the development of China's higher education [N], People's Daily, 2016, 12, 09.

[2] Xi Jinping: To Be a Good Teacher Satisfied by the Party and the People - Speech at a Dialogue between Teachers and Students at Beijing Normal University [N], People's Daily, 2014, 09, 10.

[3] Opinion of the Central Committee of the Communist Party of China and the State Council on Strengthening and Improving the Ideological and Political Work of Colleges and Universities in the New Situation [R], CPC Central Committee Issue [2016] No. 31. 